IZA DP No. 8123

A Pareto-Improving Minimum Wage

Eliav Danziger

Leif Danziger

April 2014

Forschungsinstitut

zur Zukunft der Arbeit

Institute for the Study

of Labor 


\title{
A Pareto-Improving Minimum Wage
}

\author{
Eliav Danziger \\ Princeton University
}

Leif Danziger

Ben-Gurion University and IZA

\section{Discussion Paper No. 8123 \\ April 2014}

$$
\text { IZA }
$$

P.O. Box 7240

53072 Bonn

Germany

\author{
Phone: +49-228-3894-0 \\ Fax: +49-228-3894-180 \\ E-mail: iza@iza.org
}

\begin{abstract}
Any opinions expressed here are those of the author(s) and not those of IZA. Research published in this series may include views on policy, but the institute itself takes no institutional policy positions. The IZA research network is committed to the IZA Guiding Principles of Research Integrity.

The Institute for the Study of Labor (IZA) in Bonn is a local and virtual international research center and a place of communication between science, politics and business. IZA is an independent nonprofit organization supported by Deutsche Post Foundation. The center is associated with the University of Bonn and offers a stimulating research environment through its international network, workshops and conferences, data service, project support, research visits and doctoral program. IZA engages in (i) original and internationally competitive research in all fields of labor economics, (ii) development of policy concepts, and (iii) dissemination of research results and concepts to the interested public.
\end{abstract}

IZA Discussion Papers often represent preliminary work and are circulated to encourage discussion. Citation of such a paper should account for its provisional character. A revised version may be available directly from the author. 
IZA Discussion Paper No. 8123

April 2014

\section{ABSTRACT}

\section{A Pareto-Improving Minimum Wage*}

This paper shows that a graduated minimum wage, in contrast to a constant minimum wage, can provide a strict Pareto improvement over what can be achieved with an optimal income tax. The reason is that a graduated minimum wage requires high-productivity workers to work more to earn the same income as low-productivity workers, which makes it more difficult for the former to mimic the latter. In effect, a graduated minimum wage allows the lowproductivity workers to benefit from second-degree price discrimination which increases their income.

JEL Classification: J30

Keywords: graduated minimum wage, Pareto improvement

Corresponding author:

Leif Danziger

Department of Economics

Ben-Gurion University

Beer-Sheva 84105

Israel

E-mail: danziger@bgu.ac.il

\footnotetext{
${ }^{*}$ We thank Pierre Cahuc for helpful comments.
} 


\section{Introduction}

In a competitive economy, a constant minimum wage cannot be used to make everyone better off and thereby provide a strict Pareto improvement over what can be achieved by an optimal income tax alone. Indeed, as shown by Allen (1987) and Guesnerie and Roberts (1987), a binding constant minimum wage would be counterproductive as it would reduce the hours of low-productivity workers. The reason is that the government could have attained the same lower working hours by an appropriately designed income tax alone, but has refrained from doing so. In other words, the power to set a constant minimum wage does not provide the government with an extra instrument to affect the feasible consumption-work bundles.

Subsequent papers have tried to justify the minimum wage by modifying the competitive framework and changing the objective to be to increase social welfare rather than to provide a strict Pareto improvement. Thus, if the government's social welfare function expresses a sufficiently strong taste for redistribution toward the less productive workers, combining a constant minimum wage with an optimal income tax may lead to an increase in social welfare under various circumstances. For example, if it forces some low-productivity workers to become unemployed (Marceau and Boadway, 1994); if it is combined with a welfare policy that obliges workers to accept job offers (Boadway and Cuff, 2001); if it prevents workers from signalling their earning ability (Blumkin and Sadka, 2005); or if workers with the highest disutilities of work are laid off first (Lee and Saez, 2012).

In the absence of optimal income taxation, a constant minimum wage may increase social welfare both in a competitive environment (Danziger, 2009a; and Lee and Saez, 2012) ${ }^{1}$ and in a monopsonistic environment (Robinson, 1933). ${ }^{2} \quad$ Since search frictions and informational asymmetries may lead to monopsonistic features, a constant minimum wage may be rationalized with other types of labor markets if income taxation is not optimal (Rebitzer

\footnotetext{
${ }^{1}$ See also Stewart and Swaffield (2008), De Fraja (1999), and Strobl and Walsh (2011).

${ }^{2}$ However, with optimal income taxation, monopsony cannot justify a constant minimum wage (Cahuc and Laroque, in press).
} 
and Taylor, 1995; Bhaskar and To, 1999; Cahuc et al., 2001; Bhaskar et al., 2002; Manning, 2003; Flinn, 2006; Hungerbühler and Lehmann, 2009; and Basu et al., 2010). Additionally, politics, the power of unions, and cultural factors may affect the setting of the minimum wage (Sobel, 1999; Belot et al., 2007; Boeri and Burda, 2009; Brown, 2009; Checchi and Garcia-Penalosa, 2010; Aghion et al., 2011; and Boeri, 2012).

In the current paper we pursue a different path and provide a novel justification for the minimum wage without modifying the competitive framework or changing the objective function. Our approach is designed to be as close as possible to the standard competitive model with two types of workers and optimal income taxes (Stiglitz, 1982). As we will show, our minimum wage design can provide a strict Pareto improvement of the second-best optimum achievable with taxation alone.

There is an obvious dissonance between insisting on the minimum wage being constant while allowing for a nonlinear income tax schedule. Thus, in the spirit of the optimal income tax literature, this paper analyzes a graduated minimum wage that depends on the total employment of a firm's minimum-wage workers. We show that a graduated minimum wage severs the tight connection between the wage and a workers' marginal product, thereby providing a tool for compelling firms to hire low-productivity workers at a minimum wage that exceeds their marginal product.

A graduated minimum wage can be designed so that a high-productivity worker needs to work more hours in order to earn the same income as a low-productivity worker. This makes it less attractive for high-productivity workers to mimic the low-productivity workers by earning their income. Consequently, it is easier to distinguish between workers with different productivities, and therefore also to redistribute toward the less productive workers. We prove that even if the economy is initially in a second-best optimum with an optimal income tax, both with homogenous and heterogenous firms the introduction of a graduated minimum wage can benefit all individuals and thus constitute a strict Pareto improvement.

As pointed out by Guesnerie and Roberts (1987), there is an apparent informational 
inconsistency in assuming that while the government cannot observe the workers' wages (and hence condition taxes on wages), it can nevertheless enforce a minimum wage. However, Lee and Saez (2012, p. 746) argue that even though it may not be possible for the government to observe wages, enforcement of a minimum wage can be brought about by a system of audits triggered by worker complaints and hefty penalties for noncompliant firms. ${ }^{3}$ Furthermore, as we show that there exists a graduated minimum wage schedule for which the intended minimum wage is less than the minimum wage at all but the intended working hours, a worker's complaint of being paid less than the specified minimum wage (given the firm's total employment of low-productivity workers) is equivalent to a complaint that the firm's total employment of low-productivity workers is improper (given the minimum wage).

Nevertheless, enforcement of a graduated minimum wage is likely to be more complicated and require more resources than enforcement of a constant minimum wage. However, other government programs also impose hour requirements that necessitate keeping track of the number of working hours and therefore encounter similar problems. For example, in the US, the Work Opportunity Tax Credit allows firms to claim tax credit equal to $25 \%$ of an eligible worker's first-year earnings if the individual works at least 120 hours, and equal to $40 \%$ of an eligible worker's first-year earnings if the individual works at least 400 hours. Similarly, the Welfare-to-Work Tax Credit provides firms with a tax credit of $35 \%$ of an eligible worker's first-year earnings and $50 \%$ of an eligible worker's second-year earnings if the individual works at least 400 hours. $^{4}$

If the graduated minimum wage is differentiable, we show that a firm's marginal labor cost is less than the minimum wage. Effectively, therefore, firms are facing a downwardsloping labor supply of low-productivity workers so that these workers are employed more than they would be at a constant minimum wage equal to their marginal product. In other

\footnotetext{
${ }^{3}$ Alternatively, it may be the case that a governmental enforcement agency can observe workers' wages, but that political or institutional constraints limit taxes to depend on only income.

4 The issue of noncompliance is studied in Ashenfelter and Smith (1979), Weil (2005), and Danziger (2009b, 2010).
} 
words, the graduated minimum wage endows the workers with monopoly power that allows the practice of second-degree price discrimination which increases their income.

\section{The Standard Competitive Model with Taxes}

We consider an economy with a single consumption good. There is a continuum of lowproductivity workers of measure $n_{1}>0$ and a continuum of high-productivity workers of measure $n_{2}>0$. The workers share the same preferences and their utility function is $U(c, h)$, where $c \geq 0$ is the worker's consumption and $h \geq 0$ is the working hours. The utility function satisfies $U_{c}>0, U_{c c}<0, U_{h}<0, U_{h h} \leq 0$, and the agent monotonicity property, i.e., $h U_{h} / U_{c}$ is decreasing in $h$.

The economy also includes a unit continuum of homogenous firms. A firm's production function is $f\left(\ell_{1}, \ell_{2}\right)$, where $\ell_{1}$ and $\ell_{2}$ are the total working hours in the firm of the low- and high-productivity workers, respectively. The production functions satisfy $f(0,0)=0$ and exhibit decreasing returns to scale, a decreasing marginal product of the low-productivity workers, and an imperfect substitutability between the two types of workers (i.e., the isoquants are not straight lines). Due to a bias in the production functions in favor of the high-productivity workers and/or a large ratio of low- to high-productivity workers, in all relevant allocations a low-productivity worker's marginal product is less than that of a highproductivity worker. This justifies our classification of workers as having either low or high productivity.

The low- and high-productivity workers' competitive wages are $w_{1}$ and $w_{2}$, respectively, where $w_{1}<w_{2}$. Assuming that working hours are positive for both types of workers, the decreasing returns to scale imply that profits are positive in a competitive equilibrium, i.e., $f\left(\ell_{1}, \ell_{2}\right)-w_{1} \ell_{1}-w_{2} \ell_{2}>0$. The government taxes all profits away. ${ }^{5}$ Also, we let $\left(c_{1}, h_{1}\right)$ and $\left(c_{2}, h_{2}\right)$ denote the consumption and working hours of the low- and high-productivity

\footnotetext{
${ }^{5}$ We later discuss how the assumptions can be modified so that either profits are zero or belong to firm owners who are not fully taxed.
} 
workers, respectively, where $h_{1} \equiv \ell_{1} / n_{1}$ and $h_{2} \equiv \ell_{2} / n_{2}$.

In addition to workers and firms, there is a government that wants to transfer consumption from the high- to the low-productivity workers (i.e., $c_{1}-w_{1} h_{1}>c_{2}-w_{2} h_{2}$ ). As is standard in the tax literature, taxation is based on incomes and cannot depend directly on wages. Since this rules out a first-best allocation in which lump-sum taxation is based on productivity levels, the government chooses a second-best allocation by determining a nonlinear income tax that transfers consumption from the high- to the low-productivity workers. The government's choice has to satisfy the incentive-compatibility constraints that workers of one type cannot make themselves better off by choosing their working hours so that they earn the same income as workers of the other type. To write this formally, let a circumflex over a variable denote its value in a second-best optimum with nonlinear income taxes and redistribution toward the low-productivity workers, but without a minimum wage. Then the low- and high-productivity workers' incentive-compatibility constraints are

$$
\begin{aligned}
& U\left(\hat{c}_{1}, \hat{h}_{1}\right) \geq U\left(\hat{c}_{2}, \frac{\hat{w}_{2} \hat{h}_{2}}{\hat{w}_{1}}\right), \\
& U\left(\hat{c}_{2}, \hat{h}_{2}\right) \geq U\left(\hat{c}_{1}, \frac{\hat{w}_{1} \hat{h}_{1}}{\hat{w}_{2}}\right),
\end{aligned}
$$

where $\hat{w}_{2} \hat{h}_{2} / \hat{w}_{1}$ (resp. $\hat{w}_{1} \hat{h}_{1} / \hat{w}_{2}$ ) are the hours that a low-productivity (resp. high-productivity) worker would have to work in order to reach a high-productivity (resp. low-productivity) worker's income. The agent monotonicity property implies that the incentive-compatibility constraint of the low-productivity workers (1) is slack in a second-best optimum, while that of the high-productivity workers (2) binds (Salanié, 2003).

The government's choice must also satisfy the resource constraint

$$
f\left(\hat{\ell}_{1}, \hat{\ell}_{2}\right)-n_{1} \hat{c}_{1}-n_{2} \hat{c}_{2}=R
$$

where $R$ is the government's exogenous spending need. In sum, in a second-best redistributive optimum the government maximizes $U\left(c_{1}, h_{1}\right)$ subject to a given level of $U\left(c_{2}, h_{2}\right)$ and the binding constraints (2) and (3). 


\section{A Graduated Minimum Wage}

Suppose that the low-productivity workers must be paid according to a graduated minimum wage schedule $m\left(\ell_{1}\right)$ which would make the lowest wage a firm can pay a function of the total working hours of all the low-productivity workers employed in the firm. Since any potential minimum wage must be the lowest wage in the economy (even if never chosen), $m\left(\ell_{1}\right)$ cannot exceed a high-productivity worker's wage for any $\ell_{1}$; that is, $m\left(\ell_{1}\right) \leq w_{2}$ for any $\ell_{1}$. Letting an asterisk indicate the value of a variable in an equilibrium with a graduated minimum wage, the low- and high-productivity workers' incentive-compatibility constraints become

$$
\begin{aligned}
& U\left(c_{1}^{*}, h_{1}^{*}\right) \geq U\left(c_{2}^{*}, \frac{w_{2}^{*} h_{2}^{*}}{w_{1}^{*}}\right), \\
& U\left(c_{2}^{*}, h_{2}^{*}\right) \geq U\left(c_{1}^{*}, \frac{w_{1}^{*} h_{1}^{*}}{w_{2}^{*}}\right) .
\end{aligned}
$$

Just as the income-tax function offers the workers a choice between different consumptionwork bundles, the graduated minimum wage offers the firms a choice between different minimum wage-hour bundles. With the optimal income tax one need only be concerned with determining the intended consumption-work bundles for the two types of workers (because all other bundles can be made arbitrarily unattractive). However, with the optimal graduated minimum wage one need be concerned not only with determining the intended minimum wage-hours bundle, but also with making sure that a firm's profit with that bundle is at least as high as the profit that can be attained with any other minimum wage-hours bundle. That is, a firm's choice of working hours of low- and high-productivity workers must satisfy the minimum wage constraint

$$
f\left(\ell_{1}^{*}, \ell_{2}^{*}\right)-m\left(\ell_{1}^{*}\right) \ell_{1}^{*}-w_{2}^{*} \ell_{2}^{*} \geq f\left(\ell_{1}, \ell_{2}\right)-m\left(\ell_{1}\right) \ell_{1}-w_{2}^{*} \ell_{2} \quad \forall\left(\ell_{1}, \ell_{2}\right) .
$$

Since a firm has the option of not producing by setting $\ell_{1}=\ell_{2}=0$ and hence earning zero profit, there exist working hours $\left(\ell_{1}^{*}, \ell_{2}^{*}\right)$ for which a firm's profit is nonnegative and the minimum wage constraint is satisfied. 
The resource constraint becomes

$$
f\left(\ell_{1}^{*}, \ell_{2}^{*}\right)-n_{1} c_{1}^{*}-n_{2} c_{2}^{*}=R
$$

and in an equilibrium the government's choice of a nonlinear income tax and a graduated minimum wage must satisfy the low- and the high-productivity workers' incentive-compatibility constraints (4) and (5), the firms' minimum wage constraint (6), and the resource constraint (7).

We will now show that even if the economy is initially in a second-best optimum with a nonlinear income tax that redistributes toward the less productive workers, the introduction of a graduated minimum wage can achieve a strict Pareto improvement:

Proposition 1: With homogenous firms a graduated minimum wage can provide a strict Pareto improvement of a second-best optimum with nonlinear income taxation that redistributes consumption toward the less productive workers.

Proof: In three steps we construct a graduated minimum wage that increases the utility of all workers in equilibrium.

Step 1: A Graduated Minimum Wage that Leaves the Utility of All Workers Unchanged Suppose that the graduated minimum wage be given by

$$
m\left(\ell_{1}\right)= \begin{cases}\hat{w}_{1}+\alpha & \text { for } \ell_{1}=\hat{\ell}_{1}, \\ \hat{w}_{2} & \text { for } \ell_{1} \neq \hat{\ell}_{1}\end{cases}
$$

where $0<\alpha<\hat{w}_{2}-\hat{w}_{1}$. That is, the wage is $\alpha$ higher than $\hat{w}_{1}$ at the same total hours of low-productivity workers as in the second-best allocation with only nonlinear income taxes, and $\hat{w}_{2}-\hat{w}_{1}$ higher than $\hat{w}_{1}$ at all other hours.

Let the intended consumption-work bundle for the low-productivity workers remain unchanged, which requires that their tax payment increases by $\alpha \hat{h}_{1}$. Also, let the intended consumption-work bundle for the high-productivity workers remain unchanged, which requires that the income tax when earning $\hat{w}_{2} \hat{h}_{2}$ be unchanged. The low-productivity workers' 
incentive-compatibility constraint (4) will then be the same as (1) with $\hat{w}_{1}+\alpha$ substituted for $\hat{w}_{1}$, and it will remain slack if $\alpha$ is small enough; that is,

$$
U\left(\hat{c}_{1}, \hat{h}_{1}\right)>U\left(\hat{c}_{2}, \frac{\hat{w}_{2} \hat{h}_{2}}{\hat{w}_{1}+\alpha}\right) .
$$

The high-productivity workers have to work more in order to earn the income of the low-productivity workers. Therefore, their incentive-compatibility constraint (5) will be the same as (2) with $\hat{w}_{1}+\alpha$ substituted for $\hat{w}_{1}$. As the right-hand-side of (2) decreases, their incentive-compatibility constraint is loosened and will be slack; that is

$$
U\left(\hat{c}_{2}, \hat{h}_{2}\right)>U\left[\hat{c}_{1}, \frac{\left(\hat{w}_{1}+\alpha\right) \hat{h}_{1}}{\hat{w}_{2}}\right] .
$$

If it were the case that $\alpha=0$ so that $m\left(\hat{\ell}_{1}\right)=\hat{w}_{1}$, but $m\left(\ell_{1}\right)=\hat{w}_{2}$ for $\ell_{1} \neq \hat{\ell}_{1}$, then the left-hand-side of the minimum wage constraint (6) would equal a firm's profit in the absence of a minimum wage, while the right-hand-side for any $\ell_{1} \neq \hat{\ell}_{1}$ would be less since the hourly wage of low-productivity workers have increased from $\hat{w}_{1}$ to $\hat{w}_{2}$ for any $\ell_{1} \neq \hat{\ell}_{1}$. The constraint would therefore hold with a strict inequality for all $\left(\ell_{1}, \ell_{2}\right)$ with $\ell_{1} \neq \hat{\ell}_{1}$. In reality, though, the intended minimum wage exceeds $\hat{w}_{1}$ by $\alpha>0$ so that a firm's profit at $\left(\hat{\ell}_{1}, \hat{\ell}_{2}\right)$ decreases by $\alpha \hat{\ell}_{1}$. However, for a sufficiently small $\alpha$ and any given $\ell_{1}>0$ we have that $\alpha \hat{\ell}_{1}<\left(\hat{w}_{2}-\hat{w}_{1}\right) \ell_{1}$ so that for small $\alpha$ 's the left-hand-side of the minimum wage constraint (6) is less than the right-hand-side for all $\left(\ell_{1}, \ell_{2}\right)$ with $\ell_{1} \neq \hat{\ell}_{1}$. This implies that for a sufficiently small $\alpha$ the minimum wage constraint becomes slack and a firm's profit is positive; that is

$$
f\left(\hat{\ell}_{1}, \hat{\ell}_{2}\right)-\left(\hat{w}_{1}+\alpha\right) \hat{\ell}_{1}-\hat{w}_{2} \hat{\ell}_{2}>f\left(\ell_{1}, \ell_{2}\right)-\hat{w}_{2} \ell_{1}-\hat{w}_{2} \ell_{2} \quad \forall\left(\ell_{1}, \ell_{2}\right)
$$

In actuality, therefore, the graduated minimum wage compels the firms to pay low-productivity workers more than the competitive wage while preventing them from shrinking the labor input of these workers. 
Since the workers' consumption and working hours do not change, the resource constraint will not be affected. As a result, the graduated minimum wage schedule detailed above leads to an equilibrium in which the incentive-compatibility constraints of both low- and highproductivity workers as well as the minimum wage constraint are slack. Nonetheless, the consumption and working hours of each type of worker, and hence their utilities, will be the same as in a second-best optimum with nonlinear income taxes and redistribution toward the low-productivity workers.

Step 2: A Graduated Minimum Wage Increasing the Utility of Low-Productivity Workers

In a second-best optimum with nonlinear income taxes and redistribution toward the lowproductivity workers, their marginal rate of substitution between consumption and leisure will be less than their marginal product (see Appendix). Therefore, the low-productivity workers would benefit if their working hours were increased and they would get to consume all the additional production. One implication is that there exists an increase in each lowproductivity worker's hours $\gamma>0$ such that $U\left(\hat{c}_{1}+\delta, \hat{h}_{1}+\gamma\right)>U\left(\hat{c}_{1}, \hat{h}_{1}\right)$, where $\delta \equiv$ $\left[f\left(\hat{\ell}_{1}+n_{1} \gamma, \hat{\ell}_{2}\right)-f\left(\hat{\ell}_{1}, \hat{\ell}_{2}\right)\right] / n_{1}$. Here, $n_{1} \gamma$ is the increase in the total working hours of lowproductivity workers in a firm (because there is a unit continuum of firms) and $n_{1} \delta$ is the corresponding increase in the output.

We now let the graduated minimum wage for $\hat{\ell}_{1}+n_{1} \gamma$ working hours of low-productivity workers in a firm be equal to $\left[\left(\hat{w}_{1}+\alpha\right) \hat{h}_{1}+\delta\right] /\left(\hat{h}_{1}+\gamma\right)$, and the income tax when earning $m\left(\hat{\ell}_{1}+n_{1} \gamma\right)\left(\hat{h}_{1}+\gamma\right)=\left(\hat{w}_{1}+\alpha\right) \hat{h}_{1}+\delta$ be such that the low-productivity workers' consumption is $\hat{c}_{1}+\delta$. We also let the high-productivity workers' income tax be adjusted such that if their wage changes to $\tilde{w}_{2} \equiv \partial f\left(\hat{\ell}_{1}+n_{1} \gamma, \hat{\ell}_{2}\right) / \partial \hat{\ell}_{2}$, then their consumption and working hours remain unchanged. Finally, we let the graduated minimum wage be equal to $\tilde{w}_{2}$ for $\ell_{1} \neq \hat{\ell}_{1}+n_{1} \gamma$.

The low- and high-productivity workers' incentive-compatibility constraints are

$$
U\left(\hat{c}_{1}+\delta, \hat{h}_{1}+\gamma\right) \geq U\left[\hat{c}_{2}, \frac{\tilde{w}_{2} \hat{h}_{2}}{m\left(\hat{\ell}_{1}+n_{1} \gamma\right)}\right]
$$




$$
U\left(\hat{c}_{2}, \hat{h}_{2}\right) \geq U\left[\hat{c}_{1}+\delta, \frac{\left(\hat{w}_{1}+\alpha\right) \hat{h}_{1}+\delta}{\tilde{w}_{2}}\right]
$$

and the minimum wage constraint is

$$
f\left(\hat{\ell}_{1}+n_{1} \gamma, \hat{\ell}_{2}\right)-m\left(\hat{\ell}_{1}+n_{1} \gamma\right) \hat{\ell}_{1}-\tilde{w}_{2} \hat{\ell}_{2} \geq f\left(\ell_{1}, \ell_{2}\right)-\tilde{w}_{2} \ell_{1}-\tilde{w}_{2} \ell_{2} \quad \forall\left(\ell_{1}, \ell_{2}\right) .
$$

Since the constraints (11), (12), and (13) would be identical to (8), (9), and (10) for $\gamma=$ $\delta=0$, and the latter are slack, there exist positive values of $\gamma$ for which (11), (12), and (13) are also slack. The resource constraint would also be satisfied. Hence, there is a graduated minimum wage leading to an equilibrium in which the low-productivity workers's utility increases while the high-productivity workers' utility remains unchanged.

\section{Step 3: A Graduated Minimum Wage that Increases the Utility of All Workers}

Consider a value of $\gamma$ for which (11), (12), and (13) are slack. The fact that the lowproductivity workers gain and the high-productivity workers are indifferent implies that there exists a small $\epsilon>0$ such that if, for the same intended minimum wage as in step 2, the low-productivity workers' consumption is reduced from $\hat{c}_{1}+\delta$ to $\hat{c}_{1}+(1-\epsilon) \delta$ and the high-productivity workers' consumption is increased from $\hat{c}_{2}$ to $\hat{c}_{2}+\epsilon \delta n_{1} / n_{2}$, then:

- both the low-productivity workers' utility $U\left[\hat{c}_{1}+(1-\epsilon) \delta, \hat{h}_{1}+\gamma\right]$ and the high-productivity workers' utility $U\left(\hat{c}_{2}+\epsilon \delta n_{1} / n_{2}, \hat{h}_{2}\right)$ will be higher than in the second-best optimum with nonlinear income taxes and redistribution toward the low-productivity workers;

- both the low- and the high-productivity workers' incentive-compatibility constraints will be slack, i.e.,

$$
\begin{aligned}
U\left[\hat{c}_{1}+(1-\epsilon) \delta, \hat{h}_{1}+\gamma\right] & >U\left[\hat{c}_{2}+\frac{\epsilon \delta n_{1}}{n_{2}}, \frac{\tilde{w}_{2} \hat{h}_{2}}{m\left(\hat{\ell}_{1}+n_{1} \gamma\right)}\right], \\
U\left(\hat{c}_{2}+\frac{\epsilon \delta n_{1}}{n_{2}}, \hat{h}_{2}\right) & >U\left[\hat{c}_{1}+(1-\epsilon) \delta, \frac{\left(\hat{w}_{1}+\alpha\right) \hat{h}_{1}+\delta}{\tilde{w}_{2}}\right]
\end{aligned}
$$


- the minimum wage constraint will be slack, i.e.,

$$
f\left(\hat{\ell}_{1}+n_{1} \gamma, \hat{\ell}_{2}\right)-m\left(\hat{\ell}_{1}+n_{1} \gamma\right)\left(\hat{\ell}_{1}+n_{1} \gamma\right)-\tilde{w}_{2} \hat{\ell}_{2}>f\left(\ell_{1}, \ell_{2}\right)-\tilde{w}_{2} \ell_{1}-\tilde{w}_{2} \ell_{2} \quad \forall\left(\ell_{1}, \ell_{2}\right) .
$$

Since the resource constraint continues to hold, we have proved that there exists an equilibrium with the graduated minimum wage

$$
m\left(\ell_{1}\right)=\left\{\begin{array}{cc}
w_{1}^{*} & \text { for } \ell_{1}=\ell_{1}^{*}, \\
\tilde{w}_{2} & \text { for } \ell_{1} \neq \ell_{1}^{*},
\end{array}\right.
$$

where $w_{1}^{*}=\left[\left(\hat{w}_{1}+\alpha\right) \hat{h}_{1}+\delta\right] /\left(\hat{h}_{1}+\gamma\right)$. In this equilibrium, $c_{1}^{*}=\hat{c}_{1}+(1-\epsilon) \delta ; h_{1}^{*}=\hat{h}_{1}+\gamma$; $c_{2}^{*}=\hat{c}_{2}+\epsilon \delta n_{1} / n_{2} ; h_{2}^{*}=\hat{h}_{2} ;$ and $w_{2}^{*}=\tilde{w}_{2}$. All workers obtain a higher utility than in the second-best optimum with only nonlinear income taxes and redistribution toward the low-productivity workers. This completes the proof.

As the construction of the proof of Proposition 1 shows, a strict Pareto improvement is possible because a graduated minimum wage is more efficacious than income taxes in directing resources to the low-productivity workers. Specifically, the graduated minimum wage funnels more of the firms' revenues to the low-productivity workers, thereby raising their pretax income without affecting that of the high-productivity workers (see step 1 of the proof). High-productivity workers will then have to work more in order to earn the same pretax income as low-productivity workers, and this mitigates the high-productivity workers' incentive-compatibility constraint. Consequently, the graduated minimum wage makes it easier for the government to distinguish between the low- and high-productivity workers, which facilitates a strict Pareto improvement.

The graduation of the minimum wage is essential for achieving a strict Pareto improvement, as Allen (1987) and Guesnerie and Roberts (1987) have shown that a constant minimum wage cannot do so. This is because, on the one hand, a constant minimum wage that does not exceed the competitive wage is ineffectual, while, on the other, a constant 
minimum wage that does exceed the competitive wage will reduce the working hours of the low-productivity workers. However, the same lower working hours could also have been obtained with a nonlinear income tax alone. The fact that the government has chosen not to do so reveals that it would be deleterious.

Our model assumes that the measure of firms is given and hence that there is no free entry. Together with the decreasing returns to scale and the absence of a fixed cost of production, this implies that firms earn positive profits in a second-best optimum with nonlinear taxation. These profits are fully taxed by the government, and when moving to an equilibrium with a graduated minimum wage, the graduated minimum wage is instrumental in transferring part of the profits to the low-productivity workers while the government continues to fully tax the remaining profits. Indeed, a key ingredient in the Pareto-improving mechanism is that firms can pay the low-productivity workers more than their marginal product without losing money.

If the assumption that the measure of firms is given and hence that firms earn positive profits is a concern, one could alternatively assume that the measure of firms is not given but that production involves a fixed cost. With decreasing returns to scale, firms would enter until the profits are driven down to zero in a second-best optimum with nonlinear taxation, and the economy's resource constraint would be modified by subtracting the firms' fixed costs on the left-hand side of the constraint. The government could introduce a graduated minimum wage in the same way as in the proof of Proposition 1. This would then also involve subsidizing any active firm with an amount equal to how much extra the firm is obliged to pay the low-productivity workers due to the graduated minimum wage, with the government financing the subsidies by increased taxation in the same way as it would finance an increase in its exogenous spending need for any other reason. ${ }^{6}$ This would leave the measure of firms unchanged as their profits would remain equal to zero. Accordingly, with free entry

\footnotetext{
${ }^{6}$ Government subsidy to firms can take various forms including active labor market programs (such as the Work Opportunity Tax Credit and the Welfare-to-Work Tax Credit mentioned in the introduction), guaranteed loans, start-up grants, farm subsidies, R\&D support, and preferential tax treatments.
} 
of firms and a fixed cost of production, introducing a graduated minimum wage together with a subsidy to active firms is equivalent to introducing a graduated minimum wage when the measure of firms is given, there is no fixed cost of production, and the government's spending need is raised by an amount equal to the subsidies. It follows that Proposition 1 would hold also in a case with free entry of firms, fixed cost of production, and subsidies to active firms. $^{7}$

If one keeps the assumption of a given measure of firms earning positive profits, the full taxation of the profits is important since there is then no need to worry about firm owners. However, instead of full taxation of profits, one could assume that only profits above the normal level are taxed away. The resource constraint for the economy would then be modified by adding the normal profit to the government's exogenous spending need, and Proposition 1 would state that a graduated minimum wage can provide a strict Pareto improvement for the workers while leaving the firm owners no worse off. By applying a similar argument as in step 3 of the proof of Proposition 1, the proposition could be generalized to state that there exists a graduated minimum wage which can provide a strict Pareto improvement for both the workers and the firm owners.

\section{A Continuous Piecewise Differentiable Graduated Minimum Wage}

In our formulation until now, the graduated minimum wage is not continuous at the intended working hours of the low-productivity workers (since it equals $\left[\left(\hat{w}_{1}+\alpha\right) \hat{h}_{1}+\delta\right] /\left(\hat{h}_{1}+\gamma\right)$ for the intended working hours and equals $\tilde{w}_{2}$ for other working hours). To shed further light on the source of the strict Pareto improvement, assume now that the minimum wage schedule, which we still write as $m\left(\ell_{1}\right)$, is locally differentiable at the intended working hours of the

\footnotetext{
${ }^{7}$ One could also avoid positive profits and have Proposition 1 hold by assuming constant-returns-to-scale and no fixed cost, together with a tax-financed government subsidy to active firms equaling the extra amount the graduated minimum wage forces the firms to pay the low-productivity workers.
} 
low-productivity workers. To maximize its profit, a firm would then set the low-productivity workers' hours such that the marginal labor cost, $\partial\left[m\left(\ell_{1}\right) \ell_{1}\right] / \partial \ell_{1}=m\left(\ell_{1}\right)+m^{\prime}\left(\ell_{1}\right) \ell_{1}$, equals their marginal product. Accordingly, if the minimum wage constraint is satisfied, profit maximization implies that ${ }^{8}$

$$
m\left(\ell_{1}\right)+m^{\prime}\left(\ell_{1}\right) \ell_{1}=f_{\ell_{1}} .
$$

In an equilibrium with a Pareto-improving graduated minimum wage, each firm employs low-productivity workers for more hours than it would choose if the wage were constant at $\hat{w}_{1}$ and the firm could freely decide the hours. Accordingly, the minimum wage exceeds a low-productivity worker's marginal product, i.e., $m\left(\ell_{1}\right)>f_{\ell_{1}}$. By $(14)$, this implies that the marginal labor cost of low-productivity workers, $m\left(\ell_{1}\right)+m^{\prime}\left(\ell_{1}\right) \ell_{1}$, is less than the minimum wage, $m\left(\ell_{1}\right)$, and hence that the marginal minimum wage, $m^{\prime}\left(\ell_{1}\right)$, is negative. That is, a strict Pareto improvement would be achieved by a locally differentiable minimum wage schedule that is downward sloping at the intended hours. In effect, the graduated minimum wage transforms the low-productivity workers into second-degree price discriminating monopolists that confront firms with a downward-sloping labor supply at the intended hours. The result is that the low-productivity workers are able to extract some of the firms' revenues and that they earn more than they would if the firms were permitted to pay the same minimum wage for fewer working hours.

We can now establish:

Proposition 2: There exists a continuous piecewise differentiable graduated minimum wage schedule and income taxes that can implement the same strict Pareto improvement as the non-continuous graduated minimum wage constructed in the proof of Proposition 1.

Proof: Let the intended minimum wage $m\left(\ell_{1}^{*}\right)$ and the income taxes be the same as in the proof of Proposition 1. Further, let the graduated minimum wage schedule be given by

\footnotetext{
8 The minimum wage constraint ensures that the second-order condition for profit maximization holds, i.e., that $2 m^{\prime}\left(\ell_{1}\right)+m^{\prime \prime}\left(\ell_{1}\right) \ell_{1}>f_{\ell_{1} \ell_{1}}$.
} 


$$
m\left(\ell_{1}\right)= \begin{cases}f_{\ell_{1}^{*}}+\frac{\beta}{\ell_{1}} & \text { for } \ell_{1}>\frac{\beta}{\tilde{w}_{2}-f_{\ell_{1}^{*}}}, \\ \tilde{w}_{2} & \text { for } \ell_{1} \leq \frac{\beta}{\tilde{w}_{2}-f_{\ell_{1}^{*}}},\end{cases}
$$

where $\beta \equiv\left(w_{1}^{*}-f_{\ell_{1}^{*}}\right) \ell_{1}^{*}$ and $f_{\ell_{1}^{*}}$ is evaluated at $\left(\ell_{1}^{*}, \ell_{2}^{*}\right)$. Note that the minimum wage is always continuous and that the marginal labor cost is $f_{\ell_{1}^{*}}$ for $\ell_{1}>\beta /\left(\tilde{w}_{2}-f_{\ell_{1}^{*}}\right)$ and $\tilde{w}_{2}$ for $\ell_{1} \leq \beta /\left(\tilde{w}_{2}-f_{\ell_{1}^{*}}\right)$. Thus, profit maximization implies that a firm sets the low-productivity workers' hours to $\ell_{1}^{*}$ and that the corresponding (intended) graduated minimum wage is $w_{1}^{*}$.

Since income taxes are the same as before, it is immediate that the low- and highproductivity workers' incentive-compatibility constraints and the minimum wage constraint will be slack. It is also clear that the resource constraint still holds. Hence, the same Pareto-improving equilibrium as constructed in the proof of Proposition 1 is achieved.

The graduated minimum wage used in the proof of Proposition 2 is, in the relevant range, a hyperbolic function of the low-productivity workers' hours. This implies that the marginal labor cost is a constant that equals $f_{\ell_{1}^{*}}$ independently of the value of $\beta$. Therefore, the hours are the same as they would be with a competitive wage $w_{1}^{*}$, but the low-productivity workers nevertheless succeed in increasing their total pay by an additional $\beta$.

\section{Heterogenous Firms}

We now generalize the model by allowing for heterogenous firms. Thus, suppose that there are two categories of firms, with $x_{j}$ being the measure of firms in category $j \in\{1,2\}$ and $x_{1}+x_{2}=1$. The production function of a firm in category $j$ is $f_{j}\left(\ell_{1 j}, \ell_{2 j}\right)$, where $\ell_{1 j}$ and $\ell_{2 j}$ are the total hours of labor input of the low- and high-productivity workers, respectively. The production functions satisfy $f_{j}(0,0)=0$ and exhibit decreasing returns to scale, a decreasing marginal product of the low-productivity workers, and an imperfect substitutability between the two types of workers. Each worker can only work in one firm. 
In the competitive framework with nonlinear income taxes but no graduated minimum wage, we continue to denote the low- and high-productivity workers' competitive wages by $w_{1}$ and $w_{2}$, respectively, and the high-productivity workers' consumption and working hours by $\left(c_{2}, h_{2}\right)$. We let $n_{1 j}>0$, where $n_{11}+n_{12}=n_{1}$, denote the measure of low-productivity workers who work for a firm in category $j$, and $c_{1 j}$ and $h_{1 j} \equiv \ell_{1 j} x_{j} / n_{1 j}$ denote the consumption and working hours of low-productivity workers who work for a firm in category $j$. The working hours are assumed positive for both types of workers in both categories of firms. It follows that in equilibrium all low-productivity workers will obtain the same consumption-work bundle no matter where they work, i.e., $\left(\hat{c}_{11}, \hat{h}_{11}\right)=\left(\hat{c}_{12}, \hat{h}_{12}\right)=\left(\hat{c}_{1}, \hat{h}_{1}\right)$. Furthermore, the decreasing returns to scale imply that in a second-best optimum with nonlinear income taxes, the profits are positive for both firm categories.

The low- and high productivity workers' incentive-compatibility constraints are again given by (1) and (2), with only the latter being binding, while the resource constraint is

$$
x_{1} f_{1}\left(\hat{\ell}_{11}, \hat{\ell}_{21}\right)+x_{2} f_{2}\left(\hat{\ell}_{12}, \hat{\ell}_{22}\right)-n_{1} \hat{c}_{1}-n_{2} \hat{c}_{2}=R \text {. }
$$

In a second-best optimum with redistribution favoring the low-productivity workers, the government chooses the nonlinear income tax to maximize $U\left(c_{1}, h_{1}\right)$ for a given level of $U\left(c_{2}, h_{2}\right)$ subject to the binding constraints (2) and (15).

After the introduction of the graduated minimum wage, with heterogenous firms the incentive-compatibility constraints that the low- and high-productivity workers cannot improve their utility by choosing working hours that yield the income of the other type of worker are generalized to

$$
\begin{gathered}
U\left(c_{1 j}^{*}, h_{1 j}^{*}\right) \geq U\left[c_{2}^{*}, \frac{w_{2}^{*} h_{2}^{*}}{m\left(\ell_{1 j}^{*}\right)}\right] \quad \text { for } j \in\{1,2\}, \\
U\left(c_{2}^{*}, h_{2}^{*}\right) \geq U\left[c_{1 j}^{*}, \frac{m\left(\ell_{1 j}^{*}\right) h_{1 j}^{*}}{w_{2}^{*}}\right] \text { for } j \in\{1,2\} .
\end{gathered}
$$

Further, the firms' choices of working hours for the low- and high-productivity workers 
must satisfy the minimum wage constraint

$$
f_{j}\left(\ell_{1 j}^{*}, \ell_{2 j}^{*}\right)-m\left(\ell_{1 j}^{*}\right) \ell_{1 j}^{*}-w_{2}^{*} \ell_{2 j}^{*} \geq f_{j}\left(\ell_{1 j}, \ell_{2 j}\right)-m\left(\ell_{1 j}\right) \ell_{1 j}-w_{2}^{*} \ell_{2 j} \quad \forall\left(\ell_{1}, \ell_{2}\right) \text { for } j \in\{1,2\}
$$

Since it is possible for a firm to set $\ell_{1 j}=\ell_{2 j}=0$ and obtain zero profit, for $j \in\{1,2\}$ there exist labor inputs $\left(\ell_{1 j}^{*}, \ell_{2 j}^{*}\right)$ which yield a nonnegative profit and satisfy the minimum wage constraint.

In the presence of heterogenous firms, the graduated minimum wage introduces an additional incentive-compatibility constraint for the low-productivity workers. The intended consumption-work bundles of the low-productivity workers employed in the different categories of firms must be such that those employed in one category of firms cannot make themselves better off by earning the same income as those employed in the other category. ${ }^{9}$ Thus, the additional incentive-compatibility constraint for low-productivity workers is

$$
U\left(c_{1 j}^{*}, h_{1 j}^{*}\right) \geq U\left[c_{1 j^{\prime}}^{*}, \frac{m\left(\ell_{1 j^{\prime}}^{*}\right) h_{1 j^{\prime}}^{*}}{m\left(\ell_{1 j}^{*}\right)}\right] \text { for } j \neq j^{\prime} .
$$

The resource constraint is

$$
x_{1} f_{1}\left(\ell_{11}^{*}, \ell_{21}^{*}\right)+x_{2} f_{2}\left(\ell_{12}^{*}, \ell_{22}^{*}\right)-n_{11} c_{11}^{*}-n_{12} c_{12}^{*}-n_{2} c_{2}^{*}=R .
$$

The government's choice of a nonlinear income tax and a graduated minimum wage must satisfy the low-productivity workers' incentive-compatibility constraints (16) and (19), the high-productivity workers' incentive-compatibility constraint (17), the firms' minimum wage constraint (18), and the resource constraint (20).

We now extend Proposition 1 to the case of heterogenous firms:

Proposition 3: If firms are heterogenous there exists a graduated minimum wage which can provide a strict Pareto improvement of a second-best optimum with nonlinear income taxation that redistributes consumption toward the less productive workers.

\footnotetext{
${ }^{9}$ All low-productivity workers prefer to work for the firms that pay the higher minimum wage. However, while some low-productivity workers have the good luck to be employed in those firms, others have no choice but to resign themselves to work for the lower-paying firms.
} 
Proof: Following the same logic as in the proof of Proposition 1, we use three steps to construct an equilibrium with a graduated minimum wage that increases the utility of all workers.

Step 1: Suppose the graduated minimum wage schedule is

$$
m\left(\ell_{1 j}\right)= \begin{cases}\hat{w}_{1}+\sigma & \text { for } \ell_{1 j} \in\left\{\hat{\ell}_{11}, \hat{\ell}_{12}\right\}, \\ \hat{w}_{2} & \text { for } \ell_{1 j} \notin\left\{\hat{\ell}_{11}, \hat{\ell}_{12}\right\},\end{cases}
$$

where $0<\sigma<\hat{w}_{2}-\hat{w}_{1}$ and $\sigma$ is sufficiently small that a firm in category $j$ chooses $\hat{\ell}_{1 j}$ of low-productivity workers.

In order for the low- and high-productivity workers' intended consumption-work bundles to be unchanged, let the low-productivity workers' tax increase by $\sigma \hat{h}_{1}$ and the highproductivity workers' tax be unchanged. Then, the low- and high-productivity workers' incentive-compatibility constraints (16) and (17) will be slack, and since the minimum wage is the same in all firms, the low-productivity workers' incentive-compatibility constraint (19) is satisfied. Also, the firms' minimum wage constraint (18) will be slack and the resource constraint (20) is satisfied. As a result, we have an equilibrium with a graduated minimum wage in which both the incentive-compatibility constraints that one type of worker does not want to mimic the other type and the minimum wage constraint are slack. In this equilibrium, the utilities of all the workers are the same as in a second-best optimum with nonlinear income taxes and redistribution toward the low-productivity workers.

Step 2: Recall that the low-productivity workers' marginal rate of substitution between consumption and leisure is less than their marginal product in a second-best equilibrium with nonlinear income taxes and redistribution toward the low-productivity workers. Therefore, letting the total demand for high-productivity workers be kept unchanged by adjusting their wage, for sufficiently small positive $\mu_{j}$ 's there is a graduated minimum wage with $m\left(\hat{\ell}_{1 j}+\mu_{j}\right)>\hat{w}_{1}+\sigma$ such that firms in category $j$ prefer to employ $\hat{\ell}_{1 j}+\mu_{j}$ of low-productivity workers. 
Let the income tax be such that the low-productivity workers in both firm categories get to consume all their additional production. The low-productivity workers will then be better off with their new consumption-work bundles. Furthermore, let the income tax provide the high-productivity workers with the same consumption-work bundle as before. Accordingly, there is an equilibrium with a graduated minimum wage in which the lowand high-productivity workers' incentive-compatibility constraints (16) and (17) as well as the firms' minimum wage constraint (18) are slack, and the constraints (19) and (20) hold. In the equilibrium, all the low-productivity workers obtain a higher utility and the high-productivity workers obtain the same utility as in a second-best equilibrium without a graduated minimum wage.

Step 3: Keeping the low-productivity workers' intended minimum wage and working hours in the different categories of firms as well as the high-productivity workers' wage and working hours the same as in step two, it is feasible to transfer some of the low-productivity workers' consumption to the high-productivity workers without violating any of the constraints (16)-(20). Consequently, there exists a graduated minimum wage which can provide a strict Pareto improvement.

The Pareto-improving graduated minimum wage distinguishes between different categories of firms similarly to how a nonlinear income tax distinguishes between different types of workers. Consequently, the minimum wage is generally not the same for all workers, and the graduated minimum wage therefore benefits some of the low-productivity workers more than others. ${ }^{10}$ If the graduated minimum wage in the relevant range is a hyperbolic function of the low-productivity workers' working hours, then the marginal labor cost of lowproductivity workers would be the same in both firm categories while the minimum wage would be lower in the firm category with higher employment of these workers.

\footnotetext{
10 This is consistent with the fact that in many countries the minimum wage depends on firm category. Thus, the minimum wage varies with firm size in Colombia, Honduras, and several U.S. states. Similarly, it varies with the sector or occupation in Argentina, Greece, and Ireland, and with the region in Brazil, Germany, and Mexico.
} 


\section{Conclusion}

This paper has shown that a graduated minimum wage - in contrast to a constant minimum wage - can provide a strict Pareto improvement even if the economy is initially in a secondbest optimum with a nonlinear income tax that redistributes toward the low-productivity workers. The explanation is that a graduated minimum wage allows the less productive workers to benefit from second-degree price discrimination which increases their wage and income simultaneously. This reduces the attractiveness for the more productive workers to mimic the less productive workers' income and therefore loosens the formers' incentivecompatibility constraint. As a result, a minimum wage policy can be justified without appealing to a particular social welfare function.

Our model is a first step in studying the merits of a graduated minimum wage and further research is needed to generalize the framework. It would be of interest to investigate how, for different social welfare functions, a graduated minimum wage interacts with the optimal income tax in affecting the consumption and working hours of the different types of workers in a social optimum. Likewise, it would be worthwhile to determine how a graduated minimum wage in a social optimum depends on the production technologies and the supply of the different types of workers. 


\section{Appendix}

The relevant Lagrangian is ${ }^{11}$

$\mathcal{L}=U\left(c_{1}, h_{1}\right)+\lambda_{1} U\left(c_{2}, h_{2}\right)+\lambda_{2}\left[f\left(\ell_{1}, \ell_{2}\right)-n_{1} c_{1}-n_{2} c_{2}-R\right]+\lambda_{3}\left[U\left(c_{2}, h_{2}\right)-U\left(c_{1}, \frac{w_{1} h_{1}}{w_{2}}\right)\right]$

where $\lambda_{1}, \lambda_{2}, \lambda_{3}>0$. The first-order conditions for a second-best optimum with nonlinear taxes include

$$
\begin{aligned}
\frac{\partial \mathcal{L}}{\partial c_{1}} & =\frac{\partial U\left(c_{1}, h_{1}\right)}{\partial c_{1}}-\lambda_{2} n_{1}-\lambda_{3} \frac{\partial U\left(c_{1}, w_{1} h_{1} / w_{2}\right)}{\partial c_{1}}=0 \\
\frac{\partial \mathcal{L}}{\partial h_{1}} & =\frac{\partial U\left(c_{1}, h_{1}\right)}{\partial h_{1}}+\lambda_{2} n_{1} f_{\ell_{1}}-\lambda_{3} \frac{\partial U\left(c_{1}, w_{1} h_{1} / w_{2}\right)}{\partial h_{2}}\left[\frac{w_{1}}{w_{2}}+h_{1} \frac{\partial\left(w_{1} / w_{2}\right)}{\partial h_{1}}\right]=0 .
\end{aligned}
$$

Accordingly,

$$
\begin{aligned}
& \frac{\partial U\left(c_{1}, h_{1}\right)}{\partial c_{1}}=\lambda_{2} n_{1}+\lambda_{3} \frac{\partial U\left(c_{1}, w_{1} h_{1} / w_{2}\right)}{\partial c_{1}} \\
& \frac{\partial U\left(c_{1}, h_{1}\right)}{\partial h_{1}}=-\lambda_{2} n_{1} f_{\ell_{1}}+\lambda_{3} \frac{\partial U\left(c_{1}, w_{1} h_{1} / w_{2}\right)}{\partial h_{2}}\left[\frac{w_{1}}{w_{2}}+h_{1} \frac{\partial\left(w_{1} / w_{2}\right)}{\partial h_{1}}\right],
\end{aligned}
$$

and hence

$$
-\frac{\partial U\left(c_{1}, h_{1}\right) / \partial h_{1}}{\partial U\left(c_{1}, h_{1}\right) / \partial c_{1}}=\frac{\lambda_{2} n_{1} f_{\ell_{1}}-\lambda_{3}\left[\partial U\left(c_{1}, w_{1} h_{1} / w_{2}\right) / \partial h_{1}\right]\left[w_{1} / w_{2}+h_{1} \partial\left(w_{1} / w_{2}\right) / \partial h_{1}\right]}{\lambda_{2} n_{1}+\lambda_{3} \partial U\left(c_{1}, w_{1} h_{1} / w_{2}\right) / \partial c_{1}} .
$$

Using that $w_{1}=f_{\ell_{1}}$ and $w_{2}=f_{\ell_{2}}$ we obtain that

$$
\frac{\partial\left(w_{1} / w_{2}\right)}{\partial h_{1}}=\frac{\partial\left(f_{\ell_{1}} / f_{\ell_{2}}\right)}{\partial h_{1}}=\frac{\left(f_{\ell_{1} \ell_{1}} f_{\ell_{2}}-f_{\ell_{1}} f_{\ell_{2} \ell_{1}}\right) n_{1}}{f_{\ell_{2}}^{2}}<0 .
$$

Hence, (A1) implies that

$$
-\frac{\partial U\left(c_{1}, h_{1}\right) / \partial h_{1}}{\partial U\left(c_{1}, h_{1}\right) / \partial c_{1}}<\frac{\lambda_{2} n_{1} f_{\ell_{1}}-\lambda_{3}\left[\partial U\left(c_{1}, w_{1} h_{1} / w_{2}\right) / \partial h_{1}\right] f_{\ell_{1}} / f_{\ell_{2}}}{\lambda_{2} n_{1}+\lambda_{3} \partial U\left(c_{1}, w_{1} h_{1} / w_{2}\right) / \partial c_{1}}
$$

which may be written as

$$
\frac{\theta}{f_{\ell_{1}}}<\frac{1+\psi \phi / f_{\ell_{2}}}{1+\psi}
$$

11 The proof is based on Stiglitz (1982). 
where

$$
\begin{aligned}
\theta & \equiv-\frac{\partial U\left(c_{1}, h_{1}\right) / \partial h_{1}}{\partial U\left(c_{1}, h_{1}\right) / \partial c_{1}}, \\
\phi & \equiv \frac{\partial U\left(c_{1}, w_{1} h_{1} / w_{2}\right) / \partial h_{1}}{\partial U\left(c_{1}, w_{1} h_{1} / w_{2}\right) / \partial c_{1}} \\
\psi & \equiv \frac{\partial U\left(c_{1}, w_{1} h_{1} / w_{2}\right)}{\partial c_{1}} \frac{\lambda_{3}}{\lambda_{2} n_{1}} .
\end{aligned}
$$

Since the agent monotonicity property implies that $\theta / f_{\ell_{1}}>\phi / f_{\ell_{2}}$, it follows from (A2) that $\theta<f_{\ell_{1}}$. That is, the low-productivity workers' marginal rate of substitution between consumption and leisure is less than their marginal product. 


\section{References}

Aghion, P., Algan, Y., Cahuc, P., 2011. Civil society and the state: The interplay between cooperation and minimum wage regulation. Journal of the European Economic Association 9, 3-42.

Allen, S.P., 1987. Taxes, redistribution, and the minimum wage: A theoretical analysis. Quarterly Journal of Economics 102, 477-489.

Ashenfelter, O., Smith, R.S., 1979. Compliance with the minimum wage law. Journal of Political Economy 87, 333-350.

Basu, A.K., Chau, N.H., Kanbur, R., 2010. Turning a blind eye: Costly enforcement, credible commitment and minimum wage laws. Economic Journal 120, 244-269.

Belot, M., Boone, J., van Ours, J., 2007. Welfare-improving employment protection. Economica 74, 381-396.

Bhaskar, V., Manning, A., To, T., 2002. Oligopsony and monopsonistic competition in labor markets. Journal of Economic Perspectives 16, 155-174.

Bhaskar, V., To, T., 1999. Minimum wages for Ronald McDonald monopsonies: A theory of monopsonistic competition. The Economic Journal 109, 190-203.

Blumkin, T., Sadka, E., 2005. Income taxation and wage policy: An application to minimum wage. International Tax and Public Finance 12, 713-722.

Boadway, R., Cuff, K., 2001. A minimum wage can be welfare-improving and employmentenhancing. European Economic Review 45, 553-576.

Boeri, T., 2012. Setting the minimum wage. Labour Economics 19, 281-290.

Boeri, T., Burda, M.C., 2009. Preferences for collective versus individualised wage setting. Economic Journal 119, 1440-1463.

Brown, W., 2009. The process of fixing the British national minimum wage, 1997-2007. British Journal of Industrial Relations 47, 429-443.

Cahuc, P., Laroque, G., in press. Optimal taxation and monopsonistic labor market: Does monopsony justify the minimum wage? Journal of Public Economic Theory. 
Cahuc, P., Zylberberg, A., Saint-Martin, A., 2001. The consequences of the minimum wage when other wages are bargained over. European Economic Review 45, 337-352.

Checchi, D., Garcia-Penalosa, C., 2010. Labour market institutions and the personal distribution of income in the OECD. Economica 77, 413-450.

Danziger, L., 2009a. The elasticity of labor demand and the minimum wage. Journal of Population Economics 22, 757-772.

Danziger, L., 2009b. Noncompliance and the effects of the minimum wage on hours and welfare in competitive labor markets. Labour Economics, 16, 625-30.

Danziger, L., 2010. Endogenous monopsony and the perverse effect of the minimum wage in small firms. Labour Economics 17, 224-229.

De Fraja, G., 1999. Minimum wage legislation, productivity and employment. Economica $66,473-488$.

Flinn, C., 2006. Minimum wage effects on labor market outcomes under search, matching, and endogenous contact rates. Econometrica 74, 1013-1062.

Guesnerie, R., Roberts, K., 1987. Minimum wage legislation as a second best policy. European Economic Review 31, 490-498.

Hungerbühler, M., Lehmann, E., 2009. On the optimality of a minimum wage: New insights from optimal tax theory. Journal of Public Economics 93, 464-481.

Lee, D., Saez, E., 2012. Optimal minimum wage policy in competitive labor markets. Journal of Public Economics 96, 739-749.

Manning, A., 2003. Monopsony in motion: Imperfect competition in labor markets. Princeton University Press, New Jersey.

Marceau, N., Boadway, R., 1994. Minimum wage legislation and unemployment insurance as instruments for redistribution. Scandinavian Journal of Economics 96, 67-81.

Rebitzer, J.B., Taylor, L.J., 1995. The consequences of minimum wage laws: Some new theoretical ideas. Journal of Public Economics 56, 245-255.

Robinson, J., 1933. The economics of imperfect competition. London: MacMillan. 
Salanié, B., 2003. The economics of taxation. Cambridge: MIT Press.

Sobel, R.S., 1999. Theory and evidence on the political economy of the minimum wage. Journal of Political Economy107, 761-785.

Stewart, M.B., Swaffield, J.K., 2008. The other margin: Do minimum wages cause working hours adjustments for low-wage workers? Economica 75, 148-167.

Stiglitz, J.E., 1982. Self-selection and Pareto efficient taxation. Journal of Public Economics $17,213-240$.

Strobl, E., Walsh, F., 2011. The ambiguous effect of minimum wages on hours. Labour Economics 18, 218-228.

Weil, D., 2005. Public enforcement/private monitoring: Evaluating a new approach to regulating the minimum wage. Industrial and Labor Relations Review 58, 238-257. 